原著

\title{
歯冠近遠心幅径值の分布型について
}

\author{
——多数標本に基づく検討——：第 I 報 \\ 飯田忠夫相馬邦道 三浦 不二夫 \\ 束京医科脒科大学断学部第 1 矯正学教室
}

(1985年6月29日 受付)

\section{Study on Distribution Form of Mesiodistal Crown Diameter in a Large Number of Samples : Part 1}

Tadao Iida, Kunimichi Soma and Fujio Miura

The First Department of Orthodontics, Faculty of Dentistry, Tokyo Medical and Dental University

The purpose of this paper is to examine the data distribution of the tooth size in a large number of samples. The objective teeth were the upper central and lateral incisors, upper canine, lower second bicuspid and upper and lower first molars. Their mesiodistal crown diameters were measured from 1,000 dental casts of the Japanese female orthodontic patients. On each of them, the histogram and a set of statistics, consisting of mean, standard deviation, coefficient of variance, skewness, kurtosis and Geary value were obtained in order to examine the distribution form.

As the result, these teeth were classified into the three types of distribution.

Type I : The normal distribution form was shown in the upper and lower first molars and upper central incisor.

Type II : The distorted distribution form was shown in the upper lateral incisor.

Type III : The leptokurtic distribution form was shown in the upper canine and lower second bicuspid.

As a consequence, it was suggested that it is necessary to take the greatest care in data processing in case of carrying out various statistical researches on the tooth size dealing with such teeth as Type II or III.

\section{I .はじめに}

一般に，臨床上の意志決定は，対象とする症例 を，過去の経験により構築されたモデルに投射 し，そのモデルとの適合性を，確率的に判断する ことにより行われてきているように思われる。ま た，それらに関連する臨床研究においても，その 検討の過程に，検定や推定といった統計的方法が 從来より多用されてきている。加えて, 近年の計
算機技術の進歩は, 複雑な演算処理を必要とする よらな確率論的手法に対しても沉用性を提供する までになってきている。

しかしながら、これらの確率統計的手法を用い る際に，現状は，必要不可欠な検討条件を十分吟 味せずに見過されたままで結論を求めているよう な報告が散見される。

そこで著者らは, 今回この種の確率統計的手法 の原点に戻り，最も基本的な検討条件である特性 
值の分布型に対して，多数標本を用いて検討を加 えることを目的とした。その検討対象の手はじめ として, 日常の溗正喤床の形態分析の場で用いら れてきている歯冠近遠心幅径值を用いた。

\section{II. 資料}

多数標本の観点から信頼性の高い検討を加觉る には，少なくともその標本数 1,000 を設定する必 要があると考古，今回の検討に際して，昭和 45 年 から昭和59年までに東京医科米科大学霜学部附属 病院矯正科を訪れた外来患者のなかから唇顎口蓋 㤠患者をはじめとする先天異常患者を除く，日本 人女性で永久歯列の完成している顎態模型 1,000 症例を抽出し，資料として設定した。

な抏，次項に記す計測操作に影響を与光るよう な摩耗，咬耗また潾冠部门蚛や充堫物を印象さ

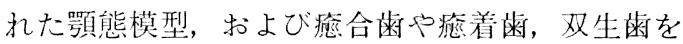
もつ䕱態模型は，あらかじめその资料の対象とは しなかった。

\section{III. 方 法}

\section{1. データの作成}

前項で設定した 1,000 症例の顎態模型上の全歯 牙の歯冠近遠心幅径值（以下，糞幅值とする）の 分布型の検討にあたり，今回の報告では，とりあ 光ず次に記す代表的な 6 歯を対象として検討を行 った。すなわち, Butler'1), Dahlberg2) により提 唱された“場の理論” (field theory)における “鍵料” (key tooth) である上顎中切歯，上顎犬 歯，上顎第 1 大四歯，下顎第 1 大臼㮀および一般 に退化傾向の強いとされる上顎側切霜, 下顎第 2 小臼菡をその対象とした。それぞれの朄の歯幅值 の計測は，左側を代表させ，その計測方法は，藤 田の方法3)に準じた。計測にはノギスを用い，そ の精度は $1 / 20 \mathrm{~mm}$ とした。なお，上顎側切柬にお ける，栓状霜や円錐歯と呼ばれるものに対して は，歯冠切䋑側 $1 / 3$ の部位に相当する近遠心幅径 をもってその值とした。また，先天欠如歯の同定 は，既往歷およびX線写真等を参照して行った。

\section{2. 検討方法}

計測された 6 米の歯幅值の分布型に検討を加え るため，以下の 3 つの方法を用いた。

第 1 の方法として，分布型を直観的かつ定性的 に把觉るこができるよらに従来より用いられて きているグラフによる表示, すなわち，度数分布 図の作成が行われた。その際の度数分布図は，そ れぞれの歯幅值が連続型変数であるため階級幅を 有するグラフ，すなわち柱状図 (histogram)を用 いた。一般に，柱状図は同一のデータを扱いな がらも設定された階級数の值によりその型が変動 するものといわれている。したがって，それぞれ の歯の本来的な分布型を調査標本によりその型を 可及的に近似させることができるように，階級数 の決定には十分に考慮を加える必要がある。そこ で, 標本数, 最大值, 最小值をパラメータとする Sturges, 国沢，清水らの階級数基準を参考にし て，歯種ごとにそれらの階級数が20２3になるよ らに決定した。なお，境界值についても，個々の 測定值が隣りあう2つの階級の境界上にくるのを 防ぐため, 測定值の精度の $1 / 2$ の值を境界値の単 位とするように考慮を加えた。そのような操作の もとに得られた柱状図を図 1 に示す。

第 2 の検討方法として，第 1 の検討方法を定量 的に補うべく，分布型に対するいくつかの統計量 の算出が行われた。これには積率 (moment) の 考允方を中心に採用した。すなわち，まず1次の 積率として，分布型の位置の測度 (measure of location) である算術平均(mean)が, 次いで 2 次 の積率として, 分布型の変動性の測度 (measure of variation) である標準偏差（standard deviation) 扣よび変動係数 (coefficient value) が算出 された。加えて, 分布型の歪度 (skewness)およ び尖度 (kurtosis) としての測度が， 3 次と 4 次 の積率をもとにして求められた。

な拈，これら歪度と尖度は，3 次と 4 次の積率 を，2次の積率で標準化したものである。すなわ ち,

$$
\begin{array}{ll}
\sqrt{\beta_{1}}=\mathrm{u}_{3} / \mathrm{u}_{2}{ }^{3 / 2} & \text { (昰度) } \\
\beta_{2}=\mathrm{u}_{4} / \mathrm{u}_{2}{ }^{2} & \text { (尖度) }
\end{array}
$$




C.M
8.875
9.075
9.275
9.475
8.675
9.875
10.075
10.275
10.475
10.675
10.975
11.075
11.275
11.475
11.675
11.875
12.075
12.275
12.475
12.675
12.875
13.075
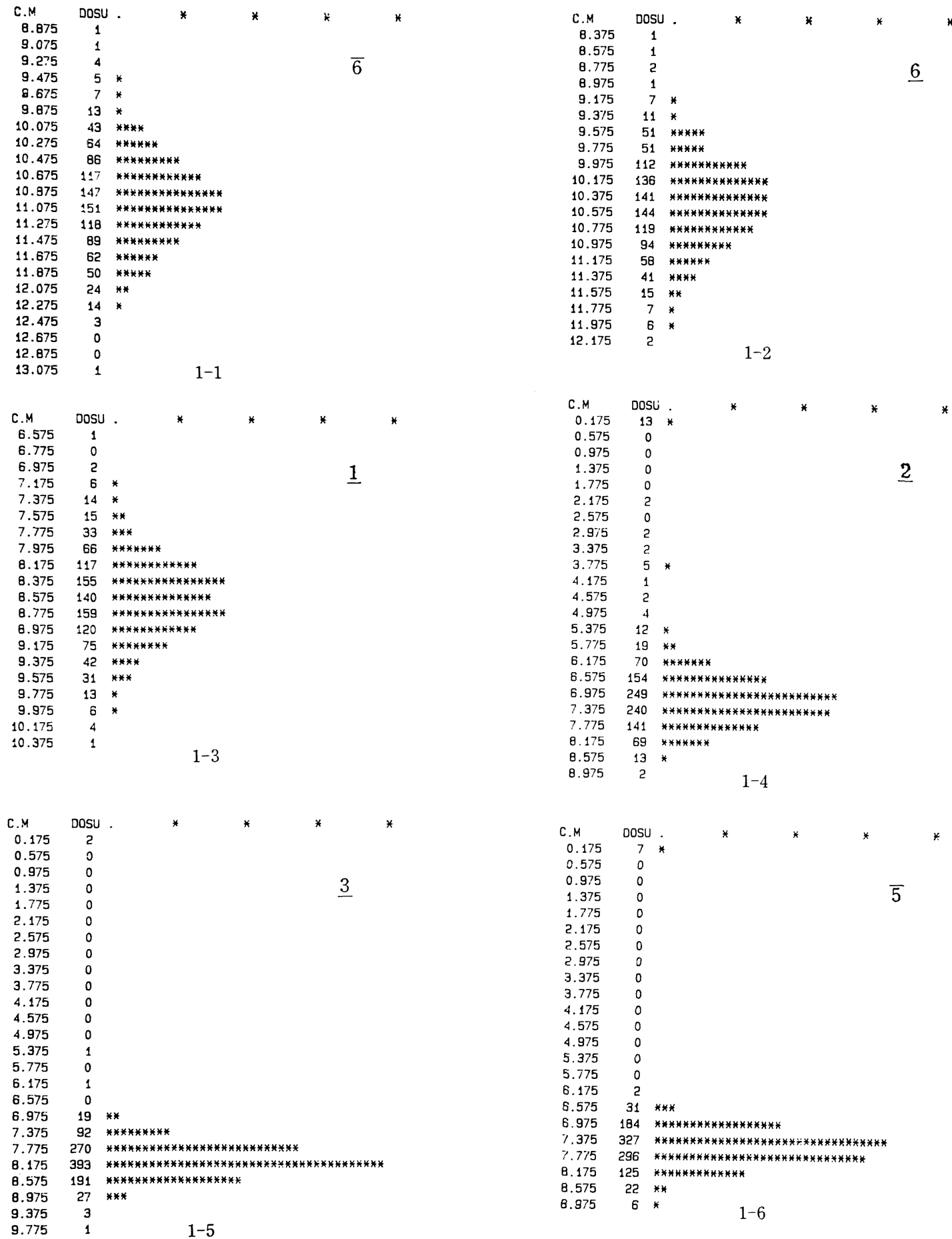

図 11 1, 000症例に基づく，6歯の歯冠近遠心幅径值の柱状図

*: 10 症例に相当（四唅五入）, C. M : 階級值 $(\mathrm{mm})$, DOSU : 症例数 
ここで,

$$
\mathrm{u}_{\mathrm{k}}=\frac{1}{\mathrm{n}} \sum_{\mathrm{i}=1}^{\mathrm{n}}(\mathrm{Xi}-\overline{\mathrm{X}}) \mathrm{k}
$$

もしも母集団分布が正規分布 $\mathrm{N}\left(\mathrm{u}, \sigma^{2}\right)$ ならば $\sqrt{\beta_{1}}=0, \beta_{2}=3$ 。

$\beta_{2}-3=0$ であるよらな分布は mesokurtic,

$\beta_{2}-3>0$ であるような分布は leptokurtic,

$\beta_{2}-3<0$ であるような分布は platykurtic, と呼ばれる4)。

第3の検討として，それぞれの歯幅值の分布型 が正規分布を呈しているか否かの検討が行われ た。これは, この種の連続型変数に対する理論度 数分布のなかで, 正規分布が従来よりの統計処理 の諸方法の基盤として最も利用されてきているも のであり, 今回の検討の 1 つに加える必要がある と考えたためである。

一般に，正規性の検討には，

1)正規確率紙の使用

2) Peason の検定 $\left(x^{2}\right.$ 検定 $)$

$3)$ 歪度, 尖度による検定 $\left(\sqrt{\beta_{1}}\right.$ 値, $\beta_{2}$ 值 $)$

4) Geary の娭定

5) Kolmogorov Smirnov の検定

などがあるが，本検討にはそのうちで最も簡単な 方法である正規確率紙による方法と, 今回のよう に標本数の多い場合に検出力が高いといわれる歪 度, 尖度法および Geary 検定が併せて用いられ た。正規確率紙による方法とは, 縦軸を $100 \%$ で 表した表にデータをプロットし，直線上に並ぶか どらかを目でみて判定する方法である。

なお, 前記の歪度, 尖度による検定方法は, 近 年若干の修正が加光られ，次式で表されるように なってきている5)。

$$
\begin{aligned}
& \sqrt{\beta_{1}}=\sqrt{\mathrm{n}} \Sigma(\mathrm{Xi}-\overline{\mathrm{X}})^{3 /}[\Sigma(\mathrm{Xi}-\overline{\mathrm{X}})]^{3 / 2} \\
& \beta_{2}=\mathrm{n} \Sigma(\mathrm{Xi}-\overline{\mathrm{X}})^{4} /\left[\Sigma(\mathrm{Xi}-\overline{\mathrm{X}})^{2}\right]^{2}-3
\end{aligned}
$$

はそれぞれ漸近的に正規分布に従う。 $\sqrt{\beta_{1}}$ につい ては, 平均 0 , 分散 $6(n-2) /(n+1)(n+3)$ とな り, $\beta_{2}$ について，仮定のもとで平均を 0 にする よらに修正された。

$\beta^{\prime}{ }_{2}=\mathrm{n} \Sigma(\mathrm{Xi}-\overline{\mathrm{X}})^{4} /\left[\sum(\mathrm{Xi}-\overline{\mathrm{X}})^{2}\right]^{2}-3(\mathrm{n}-1) /(\mathrm{n}$ $+3)$
に対して, 分散 $24 n(n-2)(n-3) /(n+1)^{2}(n+3)$ $(\mathrm{n}+5)$ を得る。これより， $\mathrm{n}$ が十分大きければ, 有意水準 $\alpha$ に対して,

$$
\begin{aligned}
& \left|\sqrt{\beta_{1}}\right|>\sqrt{6(n-2) /(n+1)(n+3)}\left\{u_{\alpha / 2}+\frac{3}{2 n}\right. \\
& \left.\left(\mathrm{u}_{\alpha / 2}^{3}-3 \mathrm{u}_{\alpha / 2}\right)\right\} \\
& {\beta^{\prime}}_{2}>\sqrt{24 \mathrm{n}(\mathrm{n}-2)(\mathrm{n}-3) /(\mathrm{n}+1)^{2}(\mathrm{n}+3)(\mathrm{n}+5)} \\
& \left\{\mathrm{u}_{\alpha / 2}+\frac{\sqrt{6}}{\sqrt{\mathrm{n}}}\left(\mathrm{u}_{\alpha / 2}^{2}-1\right)\right\}
\end{aligned}
$$

または，

$$
\begin{aligned}
& \beta_{2}^{\prime}<\sqrt{24 \mathrm{n}(\mathrm{n}-2)(\mathrm{n}-3) /(\mathrm{n}+1)^{2}(\mathrm{n}+3)(\mathrm{n}+5)} \\
& \left\{-\mathrm{u}_{\alpha / 2}+\frac{\sqrt{6}}{\sqrt{\mathrm{n}}}\left(\mathrm{u}_{\alpha / 2}^{2}-1\right)\right\}
\end{aligned}
$$

のとき仮説を棄却すればよい。

また, Geary は,

$$
\mathrm{G}=\Sigma|\mathrm{Xi}-\overline{\mathrm{X}}| / \sqrt{\sqrt{\mathrm{n} \Sigma(\mathrm{Xi}-\overline{\mathrm{X}})^{2}}}
$$

を導入した。Gは漸近的に $\mathrm{N}(\sqrt{2 / \pi},(1-3 / \pi) / \mathrm{n})$ に推うので，すその長い対称分布またはすその短 い対称分布を対立仮説と考えているよらなときに は,

$$
\left|G-\sqrt{\frac{2}{\pi}}\right|>\sqrt{1-\frac{3}{\pi}} \frac{1}{\sqrt{\mathrm{n}}} \mathrm{u}_{\alpha / 2}
$$

のとき仮説を棄却する。

ここで $\mathrm{N}=1,000$ の場合, 95\%信頼限界で,

$$
\begin{aligned}
& \sqrt{\beta_{1}}=0.15 \quad \beta^{\prime}=0.34 \\
& \left|G-\sqrt{\frac{2}{\pi}}\right|=1.32 \times 10^{-2}
\end{aligned}
$$

である。

\section{IV. 結 果}

前項で設定された方法に準じて，それぞれの歯 幅值の分布型の検討結果が得られた。度数分布図 を図 1 に, 統計量の算出結果と正規性の検定結果 とを表 1 に示す。加えて，図 2 に正規確率紙によ る検討結果を示す。

これらの結果をもとに, それぞれの歯幅値の分 布型の検討を以下に記す。

\section{1. 各雬について}

上顎中切歯の分布型：対称性がすぐれ，やや尖 りをもつが，ほぼ正規分布型に近いといえた。

上顎側切歯の分布型：分散が大で, 尖りがあ 
表 1 分布型に対する統計量の算出結果

( 1,000 症例の歯幅值)，ただし欠如歯を含んで算出

\begin{tabular}{|c|c|c|c|c|c|c|}
\hline & 平均値 & 標準偏差 & 変動係数 & 覀度 & 尖度 & Geary 值 \\
\hline$\underline{1}$ & 8.61 & 0.53 & 6.12 & $*-1.62 \times 10^{-2}$ & 0.48 & 1. $43 \times 10^{-2}$ \\
\hline$\underline{2}$ & 6.98 & 1. 10 & 15.73 & -3.77 & 20.34 & 0.22 \\
\hline$\underline{3}$ & 8.05 & 0.55 & 6.86 & -6.33 & 88.93 & 0.18 \\
\hline$\underline{6}$ & 10.47 & 0.54 & 5.16 & $*^{*} .71 \times 10^{-2}$ & $* 0.26$ & *3. $27 \times 10^{-3}$ \\
\hline$\overline{5}$ & 7. 48 & 0.76 & 10.21 & -6.47 & 61.78 & 0.27 \\
\hline$\overline{6}$ & 10.98 & 0.57 & 5.15 & $*-5.83 \times 10^{-2}$ & $* 0.28$ & *1. $23 \times 10^{-2}$ \\
\hline
\end{tabular}

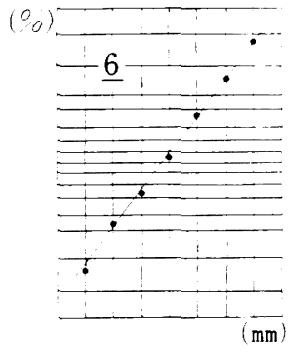

$2-1$

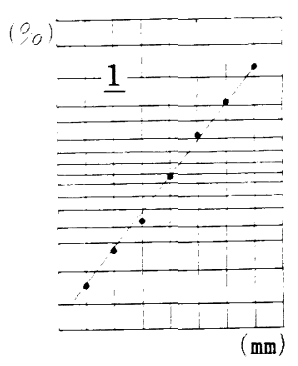

$2-3$

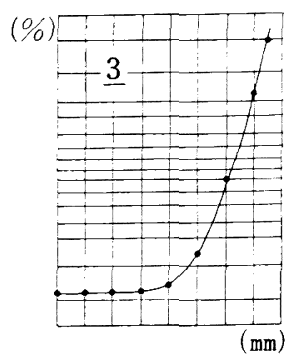

2-5

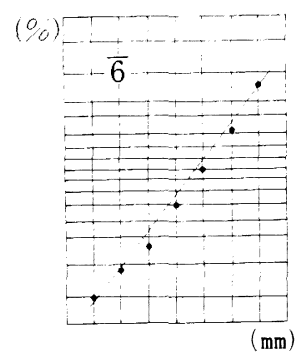

$2-2$

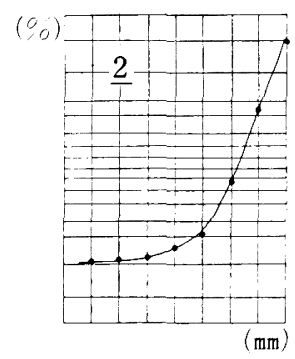

$2-4$

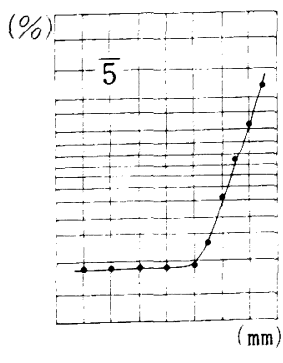

2-6

図 2 正規確率紙による 6 歯の歯冠近遠心幅径值 の検討結果

り，かつ負に歪みをもった（ピークが右に偏り， すとが左へ広がったもの）分布型であった。な お，0の度数も有していた。

上顎犬歯の分布型：尖りのある，やや歪みをも った分布型であった。なお，0の度数も有してい た。

上顎第 1 大臼雪の分布型 : 左右の対称性がすぐ れ，有意の正規分布型であった。

下顎第 2 小臼歯の分布型：尖りのある，やや歪 みをもった分布型であった。なお， 0 の度数を有 していた。

下顎第 1 大臼歯の分布型：対称性にすぐれ，有 意の正規分布型であった。

\section{2. 結果のまとめ}

表 1 か $595 \%$ の信頼限界で分布型に正規性の認 められたものは，上顎第 1 大臼歯，下顎第 1 大臼 雨の 2 歯の歯幅值であった。なお，上顎中切歯 は, わずかに尖りを有しているものの, 正規分布 型に近いものと考光られた。

一方, 上顎犬歯, 下顎第 2 小臼歯は, 歪度, 尖 度ともに大きな值を示し, 分布型は, 歪みをもち 尖りの強い(leptokurtic) 型であることが確認さ れた。また，臨床的にしばしば矮小雨や栓状雨が みられる点で興味深い上顎側切歯については, 極 めて分散の大きな負の歪みをもち, 尖りのある分 布型であることがわかった。なお，0の度数につ いては 1,000 症例中, 上顎側切歯は 13 本, 下顎第 2 小臼歯は 7 本, 上顎犬雬は 2 本であった。 


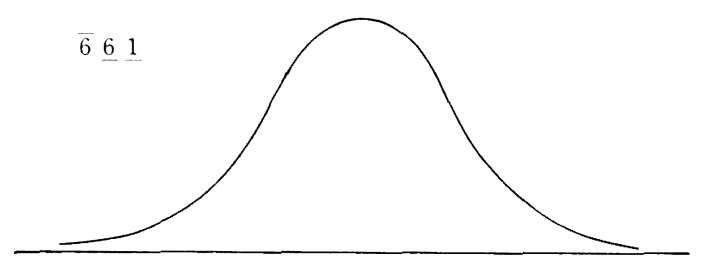

$\underline{2}$

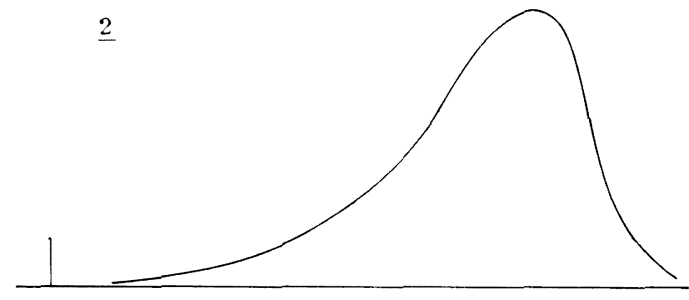

$\underline{3} \overline{5}$

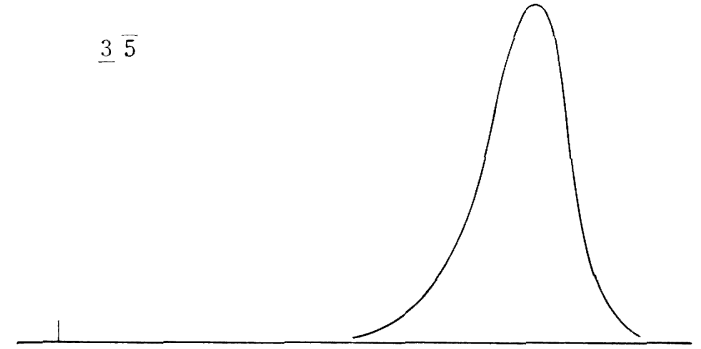

図３３つの分布型のパターン（上から正規性の高い

もの, 歪及の強いもの, 尖りの強いもの)

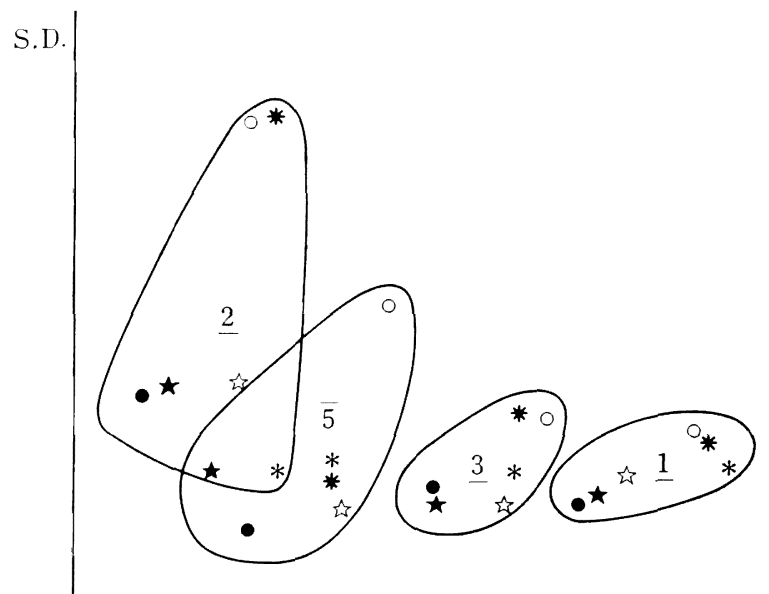

\section{L大}

以上のことより，今回計測を行った 6 歯の雪幅 值の分布型は，拈拈む称次の 3 つ型に分けるこ とができた(図 3 )。

(1)正規分布型に近似したもの；上顎第 1 大臼 歯，下顎第 1 大臼歯，上顎中切歯。

(2)尖りを有し，かつ大きく負に歪んだ分布型を 呈したもの; 上顎側切歯。

(3)わずかに歪み，かつ大きく尖った分布型を呈 したもの；上顎犬歯，下顎第 2 小臼歯。

\section{表 2 日本人歯幅値のおもな報告一覧}

\begin{tabular}{|c|c|c|c|c|}
\hline & 韩管盾 & 行 & 槽本果洲 & 標本数 \\
\hline$\star$ & 大 坪 & 1957 & 正㴗咬合者 & 55 \\
\hline 0 & 旧付 & 1965 & 止觪咬伦者 & 25 \\
\hline$*$ & 粘 川 & 1956 & 正深咬分茯 & 60 \\
\hline 米 & 粥 川 & 1956 & 仅对咬众萑 & 113 \\
\hline 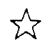 & 涑 藤 & 1970 & 一般集时 & 69 \\
\hline 0 & 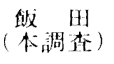 & 1985 & 镉正外来㥙者 & 1,000 \\
\hline
\end{tabular}


表 3 標本数の増減に伴ら統計量の変動のシュミレーション

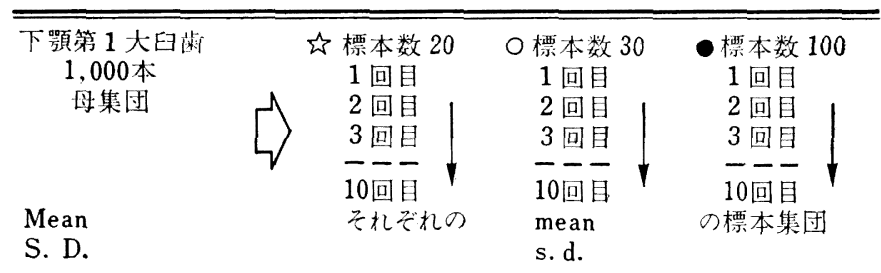

\section{V. 考察}

\section{1. 菡幅値に関する文献的考察}

日本人の歯幅值についての歯科矯正学の分野で のおもな報告は, 表 2 に示すものがあげられよ $5^{6 \sim 10)}$ 。これら報告は, 正常咬合者や一般集団, および反対咬合者などさまざまな標本集団を対象 としている。それらの報告を通じて，一般に共通 している点は, その標本数が少ないこと, および その分布型に対するパラメータに, 平均值と標 準偏差のみの統計量が扱われていることである う。そこで，さしあたりこれらの平均值と標準偏 差値について今回の計測結果とを比較桙討してみ た(図 4)。すなわち, 正常咬合者群を標本とした ものでは, その他の群を標本としたものより, 歯 幅値は平均値において全体に小さい值をしてお り, 特に下顎第 2 小臼歯にその傾向が明瞭にみら れた。また, 全報告者間において, 標準偏差值に ついては, 前歯および小臼歯での值が大きかった のに比し，大臼歯ではその值は小さい傾向にあっ た。一方, 今回の結果から正規分布型を示した上 下顎第 1 大臼歯, および上顎中切雬においては, 報告者間の平均値および標準偏差值の変動性は小 さかった。それに比し，正規性からはずれた尖り のある歪んだ分布型を呈した上顎犬歯, 上顎側切 歯拈よび下顎第 2 小臼歯に招いては, それらの值 は比較的大きな変動性を呈していた。

このように，報告者間でそれぞれの雷における 平均値および標準偏差值にかなりの変動性が存在 している理由としては，1つにはこれら報告の調 查対象, すなわち, 標本集団の性格の差がまず揭 げられようが，さらに重要な理由として，扱って

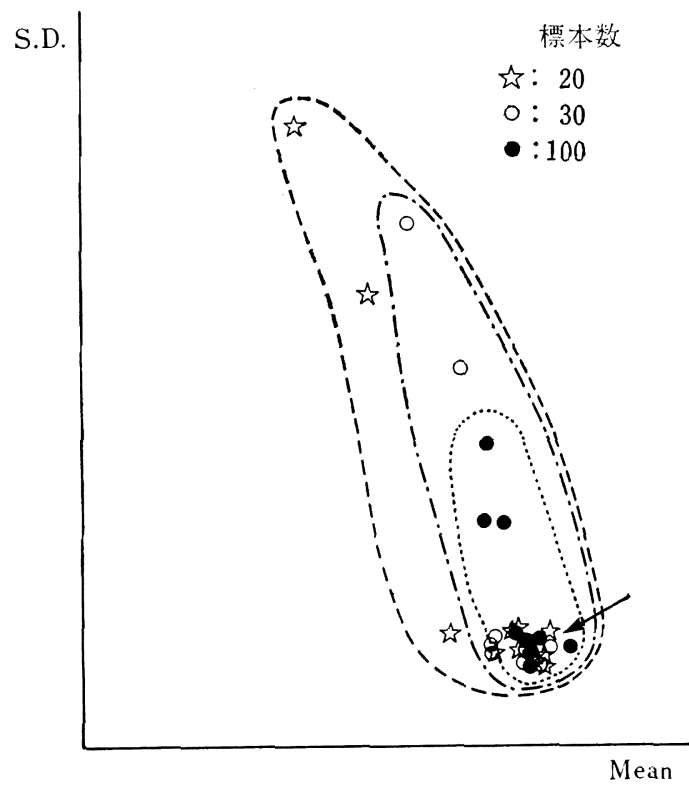

図 5 シュミレーション（表 3) の結果 (縦軸：標準偏差, 横軸: 平均值) 標本数の増加に 伴い，矢印で示す母集団の真值に漱近する

いる標本数の問題があげられよう。つまり，これ ら報告に拈いては，ほとんどが少数の標本であ り，またその信頼性に対する標本数の設定根拠も 明らかでないことにあろら。この点に関しては， 次の項で考察を加えることにする。

\section{2. 標本数と統計量について}

前項で標本数の大きさが，統計的結論に影響を 与えるらえで大きな要素であろらとの示唆を行っ た。

そこで本項では，さらにこの標本数の違いとそ れに伴って算出された統計量との間にどのよらな 関連性があるのかを, 標本数の増減を加えたシュ 
ミレーションにより検討をしてみた。シュミレー ションは表 3 に示すような方法で行った。すなわ ち，母集団として，まず，今回有意の正規分布型 を呈した下顎第 1 大臼歯 1,000 本による米幅値資 料を相当させて設定し，次に標本集団として，そ の母集団より無作為に抽出させたものを相当させ て設定した。その際の慓本数は $20 ， 30 ， 100$ の 3 とおりとし，それぞれに対し10回の復原抽出が繰 り返して行われた。な拉，検討に用いる統計量と しては，分布型を表すパラメータのらちとりあ 光ず代表的な平均值と標準偏差值が用いられた。 またこれらの比較対象に用いられる真の值には, 母集団による統計量，すなわちすでに得られてい る今回の検討結果を相当させた。それにより算出 された結果の比較を図 5 に示した。縦軸は標準偏 差，横軸は平均を表し，それぞれの設定標本数ご とに10回ずつ算出された平均値と標準偏差値が10 組の座標点として図上に描記され，それらの変動 の様相を表現させた。このことにより, 真の值と 仮定した標本数 1,000 の母集団統計量に比べ，標 本数 $20,30,100$ の標本集団のそれは, 標本数が 増加するに従い矢印で示す母集団の值に近ついて くることが認められる。また，標準偏差値の変動 は, 平均值のそ机に比べ標本数の増減に大きく影 響されていることも認められる。このことは, 平 均值は標本数の大小によらず，比較的安定した值 を示すが，標準偏差值は標本数の増減により不安 定な值を示すことを意味しているものと思われ る。換言すると，少数の標本より得られた統計量 のらち, 特に標準偏差值はその信頼性において劣 り，この点から，所見には注意をらながす必要が あろらと考えられる。

今回のシュミレーションは小規模なるのであっ たが、このような検討はさらに進めるべきもので あろら。

\section{3. 分布型について}

1)一般的観点から

本来, 医学霜学の分野におけるデータの統計処 理は，他の分野でのそれと同様に，経験的にその データの分布型を知り, 次いで理論的にそのデー
夕の確率密度関数を決定し, それを基に推定や検 定等の統計的方法を活用し結果を導出すべきもの であろら。しかしながら，通常のデータに対する 扱いは, 分布型の検討等の基礎的段階は省略し, 所与のデータはもともと正規分布型を呈している ものと仮想し, 直接統計的操作を行っているよう な報告が少なくない。確かに生体データの多くは 正規分布型に近似しており，その代表的な例とし て, 身長, 体重をはじめとする種々の臨床検査値 等があろら。しかしながら，興味あることに，過 去より，典型的な正規分布型を呈するといわれて きた身長の分布型に関しても，近年，横山 ${ }^{11)}$ は， 最大思春期性成長期の前後でその分布型は, 若干 の歪度を呈すると報告している。この事実から も, 生体のデータ分布は, それを構成する多くの 要因が複雑に関与し合っているものと推察されよ ら。今回計測を行った歯幅值のデータ分布も，そ れを構成する要因に系統発生学的要因や個体発生 学的要因等の多くの要因が複合され，その結果の 総合表現型として示されているものと考兄られ る。すなわち，上顎第 1 大臼歯，下顎第 1 大臼歯 は, 多数の要因が相互に均衡し，その結果，正規 分布型を呈し，一方，上顎側切雪は多数の要因の らちのある種の要因，たとえば霜の退化傾向を助 長するよらな要因がある程度介在したためか，分 布型に歪度を与えていた。

ちなみに, 上顎側切歯の分布型に対し, 数学的 にいくつかの適当と思われる確率密度関数を回帰 してみた。結果は，負の 3 母数対数正規分布， 4 母数対数正規分布 ${ }^{12)}$ ，および， 4 母数 $\beta$ 分布が, 同歯の分布型に近似した分布関数であることが判 明した。すなわち，上顎側切歯の歯幅值の分布型 は, 数学的観点からしても複数個の母数, つまり 複数個の要因が互いに関与し合っていることが確 認されたものと解釈されよう。加えて，このよら な分布型の解釈に関して, 梶谷は13), “混合分布 モデル”という考方方を提示しており，日常扱ら 生体データの一部は, 複数個の特性の集合である と報告している。この観点から，上顎側切歯の分 布型に対して考察してみると，図6に示すごと 


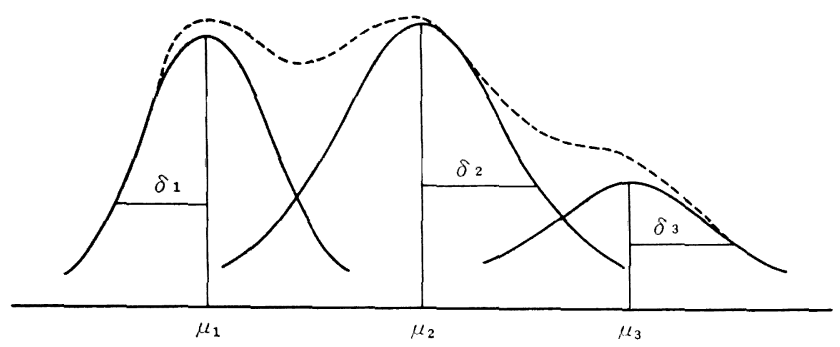

図63つの正規母集団がある比率で混じり合った混合分布 $(\text { 点線 })^{13}$

く, いくつかの正規分布型が, 混合し, その結果 として分布型に歪みを生じさせたものとも考光ら れよう。また，如齿すなわち0の度数に対する 考察としても，0の度数を生じさせる分布型が潜 在的に混入していたものと考兵るか，あるいは本 来, 極度に負の方向に歪度をもった分布が， 0 付 近では歯牙の形態形成が行わ棏ずして, その付 近の度数が 0 の度数として置き換えられたものと 考えるべきものか，見解を異にし，非常に興味あ る課題であろら。

一方, 統計量の算出方法について, 今回は欠如 歯の頻度をも含めて算出を行ってきたが, 今後, 欠如歯の頻度に左右されない分布型の検討，いい かえれば欠如歯の頻度を除いた統計量の算出法も 検討する必要があろら。

2) 矯正臨床の観点から

本項では, 歯幅値の分布型の結果を, 矯正臨林 上の観点から考察を加えてみる。

従来より，矯正の猃断や治療において患者の形 態分析を行う際，その症例を過去に集積した集団 に投射し，比較することによって症例の位置つけ を行ら方法が取られてきている。その集団は，正 常咬合者集団である場合も一般集団である場合も あるが，いずれの場合も，通常，比較の基準に標 準偏差図表が用いられる。この図表は, 集団の平 均值を中央に, その両側に標準偏差值を尺度とし た単位を用いて等分に区切られたものである。そ のため,この形式の標準偏差図表を用いる限り, 比較の基準になる集団の特性値は, 常にその分布 型の山の頂に平均値が一致し, かつ左右に歪みを もたない正規分布型であるという前提が成立して
いなければならない。矯正臨床上の歯幅値の同定 にも,この種の標準偏差図表が用いられている。 そこで, 今回の歯幅值の結果を用いて，特に上記 の点に関して考察を加えた。

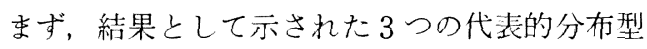
のらち，下顎第 1 大臼歯，上顎第 1 大臼歯，上顎 中切歯の歯幅值については, ほぼ正規分布型を示 したことから，標準偏差図表における前提を満足
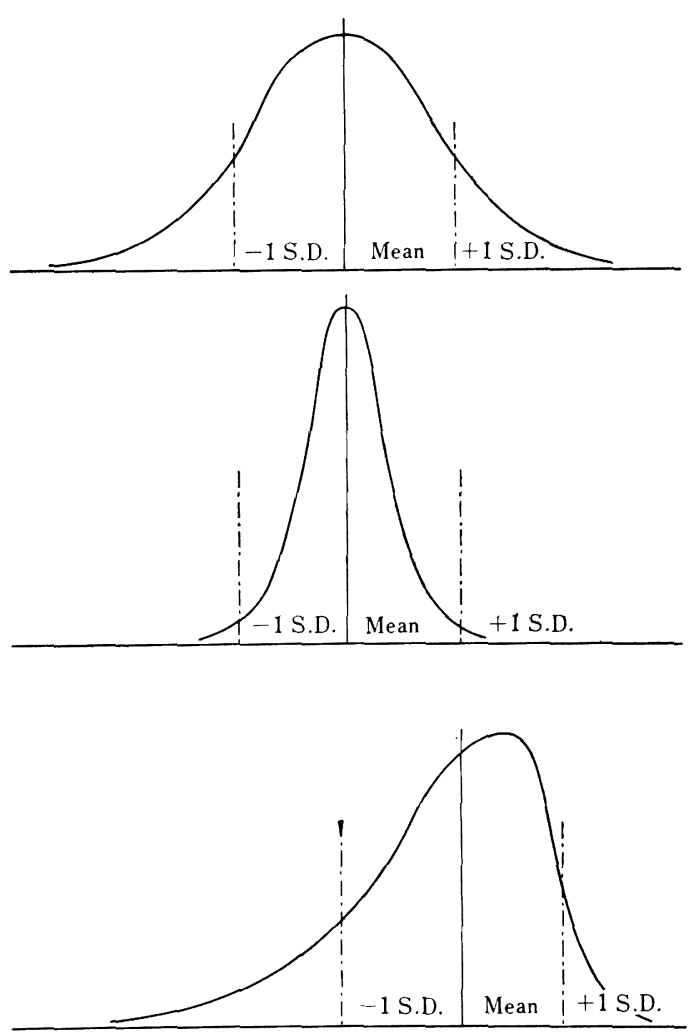

図 7 分布型の差異による平均値, 標準偏差値の比較 
しており，元のまま従来よりの分析法を適用でき よう。しかしながら, 上顎犬函, 下顎第 2 小四歯 のよらな急尖型を呈した分布型に対しては，従来 の標準偏差の概念をそのまま適用すると，図７に 示すよらになり，その尖った分布型のためほとん ぞの事象が \pm 1 S. D. (標準偏差) 以内に含まれ, 正規分布を前提としたこの図表に問題が生じてく ることになる。また，大きな歪みをもつ上顎側切 歯のよらな分布型に対しても，同様に，標準偏差 の考觉を適用すると, 平均值を中心に左右の確率 に差が生じ，奏際の現象に対して歪んだ解釈がも たらされることになる。

このよらに，尖りや丕みのある分布型を示す事 象をとのまま正規分布型を前提としたままの標準 偏差図表に適用寸ると，分析結果に渠った結論を 導き出す危険性があることを十分に配虑すべきで あろら。したがってこのよらな分布型を扱ら際 は, 統計的な前処理として, 適切な確率密度関数 をその分布に回帰させ，確率密度分布の状態をあ らかじめ把握しておくか，または，個々の変量を 変換し，正規分布に近似させるよらな操作を行ら ことが必要となってくるであろう。

\section{4. 歯幅値の歯牙相関性について}

本項では, 前項までの歯幅值の分布型の結果の 考察に加克, 得られた歯幅值そのものの結果を用 いて米牙間の相関性について考察を加えてみる。

この種の報告は, これまで Moorrees ${ }^{14)}$, 松 本 ${ }^{15)}$, 小野 ${ }^{16)}, \mathrm{Neff}{ }^{17)}$, 本橋18)によるものがあ
る。いずれも側方歯群の未萌出歯幅值の予測や, discrepancy の予測あるいは上下顎の tooth size ratio 等といった臨床的応用を意図したものであ った。今回は，計測された 6 歯のデータを用い て, 歯牙間相互の相関行列や相関散布図を求める ことにより，基礎的に検討を行うこととした（図 8 , 表 4 )。

まず，相関散布図をみると，大きく 3 つの型に 分けられよら。すなわち，上顎第 1 大臼歯と下顎 第 1 大臼歯に代表されるような相関性の高い散布 型のもの。および，上顎側切歯と下顎第 1 大曰歯 に代表されるような相関性の低い散布型のもの。 加光て，上顎中切歯之上顎側切歯に代表されるよ らな相関性の高い部分と低い部分とが混合したも のの 3 型である。

次に，相関行列表上の相関係数をみると，最も 高い值を示したものは，上顎第 1 大臼歯と下顎第 1 大臼歯の間の $\mathrm{r}=0.59$ であり, 続いて高い值を 呈したものは，上顎中切歯と上顎第 1 大臼歯の間 の $\mathrm{r}=0.48$ おび，上顎中切歯と下顎第 1 大曰歯

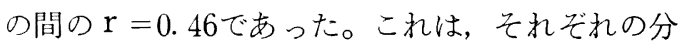
布型が安定した正規性の高いものであり，かつ咬 合関係のらえからも近縁関係にあるものと思われ る。上顎第 1 大臼歯と下顎第 1 大田歯などはその 代表例であろら。

一方, 特異的な分布型を呈した上顎側切歯と他 歯との相関性については, いずれも $\mathrm{r}=0.21$ から $\mathrm{r}=0.36$ と比較的低い値を示していた。な拈, 退

表 4 歯牙間の歯幅值の相関係数値（欠如歯を含んで算出）

右上部；原計測值を用いて算出

左下部; 下顎第 1 大臼歯との比を用いて算出

\begin{tabular}{l|llllll}
\hline & $\underline{1}$ & $\underline{2}$ & $\underline{3}$ & $\underline{6}$ & $\overline{5}$ & $\overline{6}$ \\
\cline { 2 - 7 } & \multicolumn{1}{c}{} & 0.3860 & 0.4097 & 0.4897 & 0.2397 & 0.4697 \\
$\underline{2}$ & 0.3587 & & 0.2586 & 0.2490 & 0.2236 & 0.2152 \\
$\underline{3}$ & 0.4305 & 0.2397 & & 0.3615 & 0.2086 & 0.3320 \\
$\underline{6}$ & 0.4485 & 0.1948 & 0.3771 & & 0.3397 & 0.5915 \\
$\overline{5}$ & 0.2470 & 0.2164 & 0.2373 & 0.3488 & & 0.2488 \\
$\overline{6}$ & $\ldots \ldots \ldots$ & $\ldots \ldots \ldots$ & $\ldots \ldots \ldots$ & $\ldots \ldots \ldots$ & $\ldots \ldots \ldots$ & \\
\end{tabular}




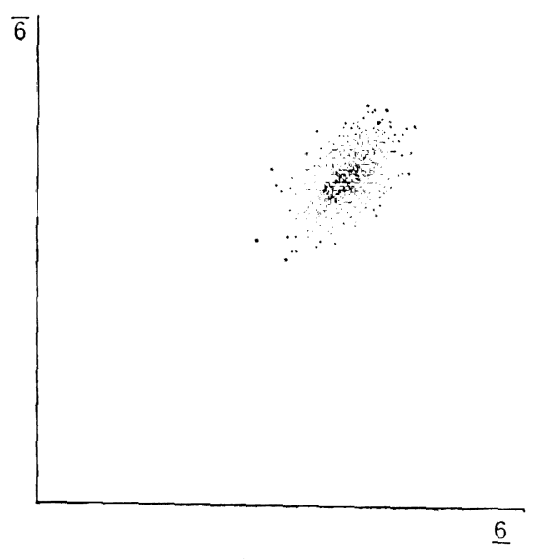

$8-1$

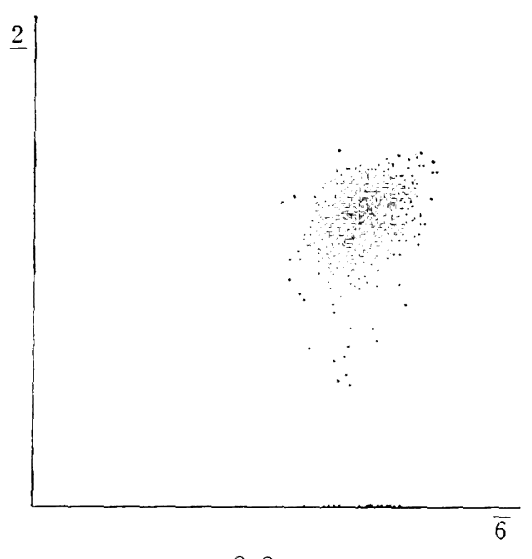

$8-2$

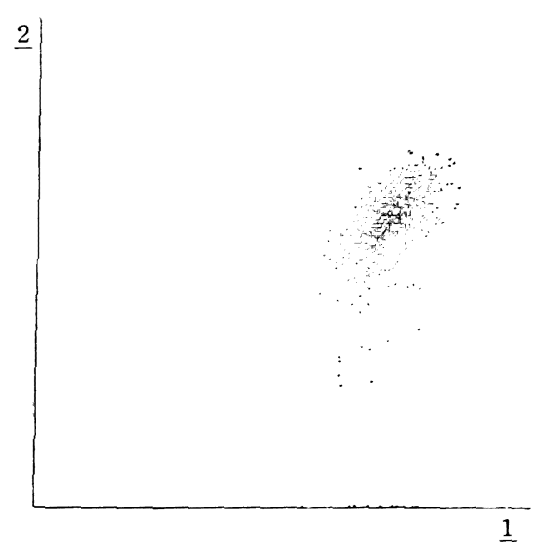

8-3

図 8 歯牙間の蒾幅値の相関散布図 上図 (8-1): 相関の高いもの 中図 (8-2): 相関の低いもの 下図 (8-3): 混合したもの

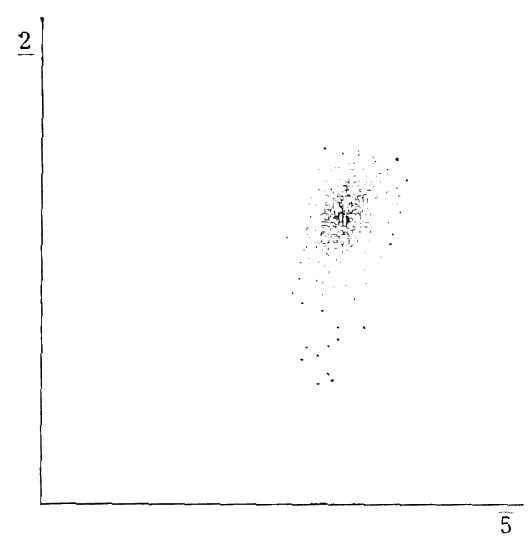

図 9 上頡侧切歯と下頡第 2 小曰歯の相関散布図 特に高い相関の散布状態は示していない

化傾向にあるといわれている上顎側切蒾と下顎第 2 小曰歯との相関性に関しては，きわだった関連

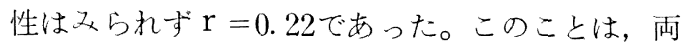
者の散布図からも確認さ机上ら(図 9 )。さらに, 上顎側切歯之下顎第 2 小目苯とともに久如を示し た例を検索してみると 1,000 例中 1 例のみであっ た。したがって、こ机らの事実から両者の退化傾 向は歯幅值に関してはそれぞれ独立な事象と思わ れた。

さて，ここで相関係数の有意水準について統計 学的にみると, 標本数 1,000 とした際, 危険率 1 \%レベルでの有意の相関係数値は $\mathrm{r}=0.081$ とな る。この值をそのまま今回の結果に適用すると, すべての荬牙間で有意な值をもつことになる。こ のことは, 全歯牙間に共通した背景の要因が存在 することが示唆され，その要因のなかでも最も主 たるものとして個々体に潜在的にある大きさの要 因が揭げられよう。そこで, 計測されたデータそ れぞれに対し大きさの要因の基準化を行って検討 を進める必要があると考光た。今回は, その試又 として，比較的安定した分布型を示した下顎第 1 大臼歯を基準化のパラィータとして用いることに した。したがって，その歯の值と各歯牙の值との 比の値を新しい変量として設定し，これを基にさ らに相関性の検討を行った。基準化を施したのち の新しい相関值の結果を表 4 の左下の三角行列部 
分に示す。

最も相関㑑の高くなったものは，上顎中切蔽と 上顎第 1 大曰歯の $\mathrm{r}=0.44$, 最も小さくなったも のは, 上顎倒切秚之上顎第 1 大臼歯の $r=0.19 て ゙$ あった。

この結果と関連して與味あることは，従来より field theoryに拊ける key tooth とされる上顎中 切歯と犬歯にはさまれた側切歯は，どちらの歯に より高い相関值を示すかという点である。今回の 結果では, 一方の $r=0.35 に$ 対して他方は $r=$ 0.23 となっており, 上顎中切畨のほうにより高い 相関值を示すことが認められた。

最後に再確認すべきことは，歯幅值相互の相関 係数值は, 単に統計学的な值であり, その值や絬 果を生物学的な関速性に直接結びつけるべきでは なく，一般的な傾向を又る1つの目安であると考 光，もしそこに生物学的解利に矛盾のある場合 は, 今回行ったような基準化などの操作を適宜行 らことにより，総合的に柍刢を加えてゆくべきも のであろう。

\section{VI. ま め}

顎顔面領域における諸々の特性值の多数標トに よる本来的な分布型を調べる目的で，ての手はじ めとして，歯冠近遠心幅径优を用いて娭討を行っ た。資料は, 東京医科米科大学霜学部附属病院镉 正科外来を訪九た患者资料から，先天異常患者を 除く，永久歯列の完成した日仁人女性の顎態模型 1,000 症例を抽出して用いた。計測対象とした将 は, 上顎の中切蒌, 側切歯, 犬蒾, 第 1 大曰雬,

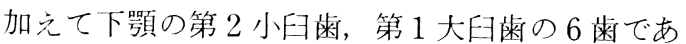
った。また，分布型の検討には，それぞれの歯に ついて求められた柱状図や一連の統計聂（平均 值, 標準偏差值, 赑動係数, 歪度, 尖度, Geary 值）が用いられた。

その結果, 6 䊝の粦幅値の分布型は, お扣むね 次の 3 型に分けられた。

1正規分布型に近似したもの；上顎第 1 大日

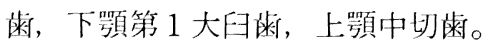

2尖りを有し，かつ大きく負に歪んだ分布型を
呈したもの；上顎側切雪。

(3)わずか歪み，かつ大きく尖った分布型を呈 したもの；上顎犬米，下顎第 2 小臼歯。

したがって，上顎側切歯，上顎犬歯扣よび下顎 第 2 小四歯のような正規分布型を呈しない歯を扱 った歯幅值の統計的研究を行ら際には，それらの データ処理に十分注意を払ら必要性が 示㖫され た。

また，得られた結果を基に考察を加えたとこ ろ, 以下の知見も追認された。

1)慓本数の増減と統計量の変動に関してシュミ レーションを行ったところ, 平均値は, 標本数の 增減に対して，比較的安定した值を示したが，標 準偏差は不安定な值を示した。

2) 歯牙相互間の相関性において，上顎第 1 大曰 桃，下顎第 1 大臼歯および上顎中切歯の間には比 較的高い相関係数值を示していた。なお，互いに 退化傾向にあるといわれている上顎側切歯と下顎 第2 小四歯との間には，歯幅值における統計的有 為性は認められなかった。

\section{謝辞}

稿を終えるにあたり，統計的観点より有益なご助言 をいただきました中央大学理工学部数学科, 杉山高一 教授に感謝をいたします。

\section{文献}

1) Butler, P. M. : Studies of Mammalian Dentition, Differentiation of Postcanine Dentition. Proc. Zool. Soc. 109 : 36, 1939.

2) Dahlberg, A. A. : The Dentition of the American Indian. New York, 1945, The Viking Fund Inc., 1949

3）藤田恒太郎：歯の解剖学 (第18版). 東京, 1972 , 金原出版, 25-26.

4）增山元三郎：少数例のまとめかた. 東京, 1975 , 竹内書店新社.

5）清水邦夫：私信.

6）大坪淳造：日本人成人正常咬合者の歯冠幅径と 歯列弓および Basal Arch との関係について. 日矯蔽誌 16(1)：36-46, 1957.

7）山内和夫：日本人青年男女正常咬合者の歯牙扰 よび歯列の計测. 日矯歯誌 $24: 1-7,1965$.

8）遠藤 孝：“下顎前突の疫学的研究”一般集団 における下顎前突の実態. 日矯齿誌 $30: 73-$ 
$77,1971$.

9）遠藤 孝: 歯列咬合に関する疫学的研究. 日矯 歯誌 $29: 111-126,1970$.

10）粥川浩：いわゆる反対咬合の形態学的研究, 第一編：模型分析による研究. 日矯陱誌 15 : 6, 1956.

11）横山泰行：青少年の身長の正規性に関する研究 一 $\mathrm{k}$ 統計量正規性検定法による一. 人類誌 86 (4) : 313-320, 1978.

12) J. A. Lambert : Estimation of Parameters in the Fourparameter Lognormal Distribution. Austral. J. Statist $12(1): 33-43,1970$.

13）暒谷文彦：臨床検査の確率分布モデル，総合臨 床 $27: 2011-2017,1978$.
14) Moorrees, F. A. : Correlation among Crown Diameters of Human Teeth. Arch. Oral. Biol. 9 : 685-697, 1964.

15）松本光生：上下歯冠幅径の調和. 日矯歯誌 30 (1) : 53-55, 1971.

16）小野博志：乳歯拉よび永久歯の歯冠近遠心幅径 と各䨑列内に拈けるその相関について。只病誌 27 : 221-234, 1960.

17) Neff, C. W. : Size Relationship Between the Maxillary and Mandibular Anterior Segment of the Dental Arch. Angle Orthod. $27: 138$ 147, 1957.

18）本橋康助, 他：Tooth-Size Ratio の臨床応用に ついて. 日矯蔽誌 16(1) : 36-46, 1957. 